\title{
Report on Canadian Film Archives
}

\author{
By Gerald Pratley
}

Spring 2007 Issue of KINEMA

INTERNATIONALLY, there are Archives, Archives, Archives, from Film to TV - but where to put them and what to keep? Canada makes some progress. At almost every film festival, internationally, when early print of a classic turns up, the question permanently asked is where did that print come from? And the answer is usually from such and such an Archive in some part of the world. For Canadians, the Archive was a seldom visited place in Ottawa, where somewhere films in dented cans or broken boxes, hardly separated from papers, journals, and material having little to do with movies.

In spite of the clamour from film enthusiasts, the federal government remained unmoved, while the staff, without temperature control, tried to keep them from becoming dead reels. Now, after years of pleading and asking the Dominion Government has finally built an astonishing film archive across the river from Ottawa in the Gatineau. It is so imaginative and impressive making it difficult to believe it's actually real! An immense highly arched glass and steel building, almost beyond description, with twenty great pipes going into it, providing the essential elements to make the archives safe and secure, with the interior design by the Ottawa architect Ronald Keenert, containing great floors, walls with a massive use of concrete, with great windows everywhere bringing in the light, but not of course on the deposits, safe in their quarter, from the movies, to the millions of records of national significance, with the emphasis always on the conservation.

And where films are concerned there is nothing the Archive cannot do in its futuristic labs from showing them in their extensively equipped screening theatre, to making new copies, repairing others, with no end to the comprehensive work the archivists do in saving and storing prints and negatives. There are over 60,000 Canadian prints in all gauges. In long seemingly never ending rows stretching for a distance longer than the eyes can see. Every reel is in its own plastic container, and again temperature controls are tightly maintained. Numbers, not titles, are around the rims. My guide pulled one down, opened it, the first reel of Don Shebib's 1970 Goin' Down the Road, not the oldest by any means, yet until now, along with other early works before this time. With electronics everywhere, the finding the title was an instant act, along with a full description of the film. Together with this outstanding archive is another building, somewhat like a place of business, but also impressive, where special collections of files, posters, publications, anything about the prints and others quickly found. The Federal Government has spent over $\$ 95$ million, and got it right for once. Canada is now among the best with those of the United States, United Kingdom, France, but the name has been changed. National Film Archive has been lost and is now part of the Social and Cultural Division of the Special Collections Branch. It is open to the public, and parking, its beautiful grounds is free. This huge enterprise depends on a small number compared to those in archives elsewhere, but efficient and devoted conservators, under the leadership of chief archivist, Ian Wilson.

And Canadian producers should take note that movies made with funds from Telefilm, the state funding office, must donate two prints. Most producers and filmmakers themselves, who did not receive grants, are pleased to donate their prints and negatives knowing they will be there for generations of film lovers for centuries to come!

And so finally, a dream from lone ago is finally brought to life. I remember back in the fifties and sixties, when along with historians Hye Bossin, Sam Kula, and the then head archivist, Dr. W. Kaye Lamb, and Secretary of State Judy LaMarsh, we met frequently to talk about establishing a truly great National Film Archive for Canada. Now we have it!

\section{Author Information}

Gerald PRATLEY, OC, LLD, started his career as film critic with the CBC. In 1969, he founded the Ontario Film Institute which he directed until 1990. He has written several books and numerous articles on film, including Torn Sprockets, a history of Canadian cinema. He taught Film History in universities in Toronto and Waterloo, Canada and holds three honorary degrees from Canadian and US universities. 
Gerald A. Pratley (1923-2011) was born and educated in London, England, and came to Canada in 1946. He started working in Toronto for the $\mathrm{CBC}$ as a scriptwriter. He was drawn toward working in motion pictures, and became, in 1948, the CBC's first film critic and commentator.

Gerald Pratley broadcast three programmes a week, Pratley at the Movies, The Movie Scene, Music From the Films, and others, until 1975. During this time he also became the first post-war chairman of the Toronto Film Society, chairman of the Toronto and District Film Council and co-founder of the A-G-E Film Society and correspondent for international magazines such as Films and Filming, Film In Review, Variety, Hollywood Quarterly and International Film Guide. During the 1950s he wrote for Canadian Film Weekly and Canadian Film Digest.

He became known as a speaker on all aspects of motion picture art and industry, and was invited to teach film history at the University of Toronto, York University, University of Waterloo, Seneca College and Ryerson Polytechnical University, with individual lectures being given at many other Canadian and US universities and colleges. He has served as a member of various judging panels of competitions and festivals, being one of the members of the first Canadian Film Awards in 1949.

From 1970 to 1975 he was the director of the Stratford (Ontario) International Film Festival, and from 1969 to 1976 he was Chairman of the International Jury of the Canadian Film Awards. He has attended all the world's leading festivals of film, and in particular, for 30 years, the Cannes Festival as CBC correspondent. He has written six books, The Films of Frankenheimer: Forty Years in Film; The Cinema of John Frankenheimer; The Cinema of Otto Preminger; The Cinema of David Lean; The Cinema of John Huston, and Torn Sprockets, a history of the Canadian cinema.

Gerald Pratley has served on the Advisory Boards of the film departments of Ryerson Polytechnical University and Humber College, and as a member of the programme committee of TV Ontario. In 1968 he became the founder-director of the Ontario Film Institute of the Province of Ontario, an organization which has distinguished itself in archival holdings and public service and is known since 1990 as the Cinematheque of Ontario. He taught Film History courses at the Department of Film and Photography, Ryerson Polytechnic University, Toronto and the University of Waterloo.

In 1984, Gerald Pratley was made a Member of the Order of Canada and in 2003 Officer of the Order of Canada for his service to Canada through film appreciation. He holds Honorary Degrees in Letters and Fine Arts from York and Waterloo Universities (Ont., Canada) and Bowling Green State University (Ohio, USA).

In 2002, Gerald Pratley received a Special Genie Award from the Academy of Canadian Cinema \& Television in recognition of his lifelong dedication to the promotion and his exceptional support of Canadian cinema.

He died on 14 March 2011 in Ontario, Canada. 